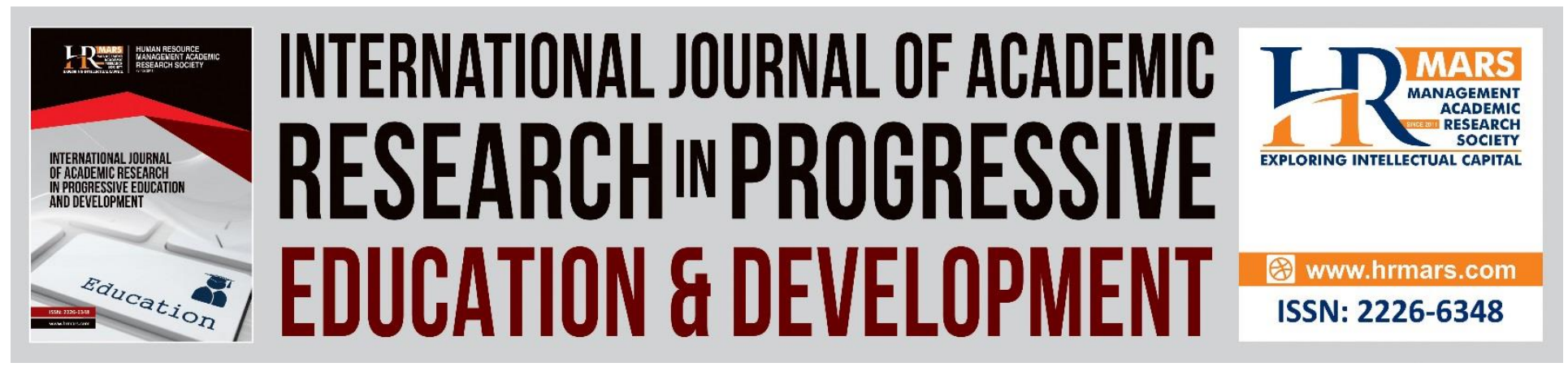

\title{
Enhancing Mathematical Performance Using Fun Teaching Aids
}

Kho Ling Hong, Izzat Syahir Mohd Ramli, Nor Afifah Mazlan, Madavi Rengasamy, Hii Lu Kong, Kogilavani Muniandi

To Link this Article: http://dx.doi.org/10.6007/IJARPED/v9-i2/7486 DOI:10.6007/IJARPED/v9-i2/7486

Received: 12 April 2020, Revised: 16 May 2020, Accepted: 23 June 2020

Published Online: 30 July 2020

In-Text Citation: (Hong et al., 2020)

To Cite this Article: Hong, K. L., Ramli, I. S. M., Mazlan, N. A., Rengasamy, M., Kong, H. L., \& Muniandi, K. (2020). Enhancing Mathematical Performance Using Fun Teaching Aids. International Journal of Academic Research in Progressive Education and Development, 9(2), 440-448.

Copyright: (C) 2020 The Author(s)

Published by Human Resource Management Academic Research Society (www.hrmars.com)

This article is published under the Creative Commons Attribution (CC BY 4.0) license. Anyone may reproduce, distribute, translate and create derivative works of this article (for both commercial and non-commercial purposes), subject to full attribution to the original publication and authors. The full terms of this license may be seen at: http://creativecommons.org/licences/by/4.0/legalcode

Vol. 9(2) 2020, Pg. 440 - 448

http://hrmars.com/index.php/pages/detail/IJARPED JOURNAL HOMEPAGE

Full Terms \& Conditions of access and use can be found at http://hrmars.com/index.php/pages/detail/publication-ethics 


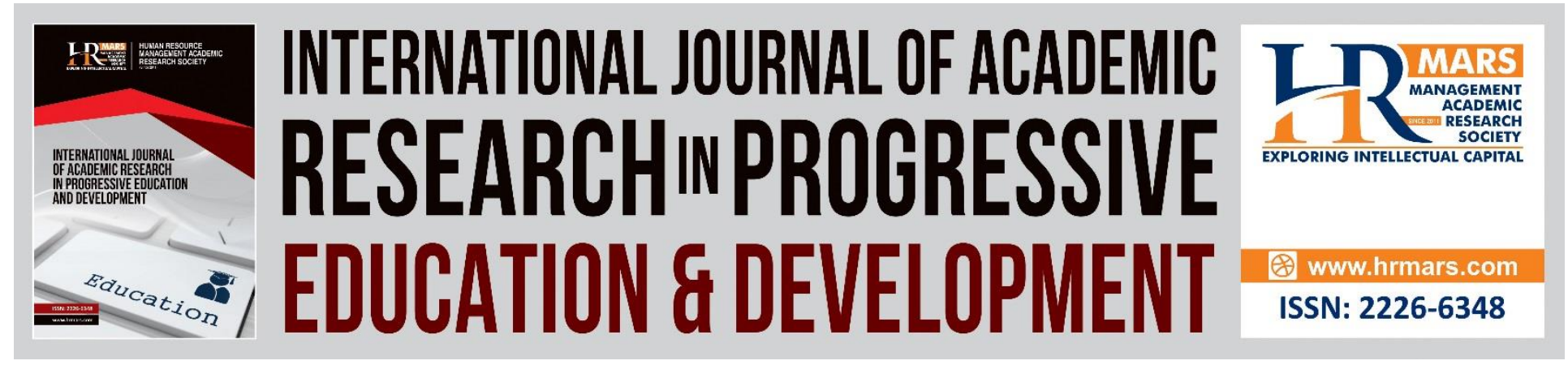

\title{
Enhancing Mathematical Performance Using Fun Teaching Aids
}

\author{
Kho Ling Hong ${ }^{1}$, Izzat Syahir Mohd Ramli², Nor Afifah Mazlan³, \\ Madavi Rengasamy ${ }^{4}$, Hii Lu Kong ${ }^{5}$, Kogilavani Muniandi ${ }^{6}$ \\ 1,4,5 Pejabat Pendidikan Daerah Subis, Sarawak, ${ }^{2}$ SK RH Ranggong, Sarawak, ${ }^{3}$ SK Sg. Lamaus, \\ Sarawak, ${ }^{6}$ Pejabat Pendidikan Daerah Seberang Perai Selatan, Pulau Pinang \\ Email: ${ }^{1}$ linghongkho@gmail.com, ${ }^{2}$ ejat.mu89@gmail.com, ${ }^{3}$ afifahizzat14@gmail.com, \\ ${ }^{4}$ madhunism@gmail.com, 5williamhiilukong@gmail.com, 6getzvanee@gmail.com
}

\begin{abstract}
Fraction, Decimals and Percentages (FDP) are important basic skills that are applied in a variety of Mathematics topics such as Whole Number, Length, Mass and Volume of Liquid. Pupils get discouraged when they make continuous mistakes, which make them lose interest in Mathematic. This is due to weak in basic skill knowledge such as terms of pronunciation or its usage in solving mathematical problems. The innovation of "Where's My Family Games" which uses fingers and Fun Teaching Flash cards is solely to address and counter these problem among pupils. Through this variety of games, pupils should be able to form deep mathematical ideas and opportunities. This innovation plays the purpose of helping pupils to strengthen the usage of basic knowledge in converting units that enable them to use it in a variety of Mathematical topics. With the support of Constructivism Theory, "Where's My Family Games" is innovated where Teaching Flash Cards are used in applying mathematical techniques, terms and logic plus reasoning. An experiment conducted using the design, One-Group Pre Test - Post Test Experiment that involves 50 pupils of Year 5 from rural primary schools. We used descriptive statistic to analyse the data obtained from the pre-test and post-test. The pre-test showed that 48 pupils (96\%) were in the weak level, where else 2 pupils were in moderate level (4\%). Meanwhile, the post-test showed a promising increment which 15 pupils (30\%) in excellent level and $25(50.00 \%)$ in medium level. The pre-test mean score shows an increment from $6.93 \%$ to $63.73 \%$ in the post-test. This clearly shows that the Year 5 pupils were able to understand converting units better, easily and swiftly. In order to encourage pupils to be more involved and have deep understanding on converting units, "Where's My Family Games" comes in to give a helping hand.

Keywords: Mathematics, Basic Knowledge of Mathematics, Converting Units, Fun Teaching, Primary School.
\end{abstract}




\section{Introduction}

Mathematics plays an important role in everyday life. Knowledge that is used by pupils in developing problem solving skills, communicate and critical thinking and being systematic are results of learning Mathematics. According to Azlina (2003), Mathematics is one of the subjects considered a "killer subject". Unfavourable achievements put Mathematic teachers, parents and pupils themselves in great dismay. Widad (1998) states that teachers are the main factor in contributing to pupils' academic excellence.

Due to this, a wise teacher will strive to teach something useful in the process. As teachers, we have to step up and change the mundane teacher centred teaching that emphasizes on drilling, memorising tips and formulas. Learning of Mathematics will occur when pupils can build math concept by themselves through fun and interesting activities. According to Ali, Aziz \& Majzub (2011), "playing" is an important element in a child's life. Children learn about their environment and surrounding through games. This shows that, experience and knowledge can be built indirectly. Pupils will not feel that there are in the process of learning because they are engrossed in the fun and excitement of playing. Learning through games definitely brings many benefits.

Teaching and learning approaches through games will also encourage pupils to learn while playing. Learning through games will stimulate the minds of pupils towards the construction of mathematical knowledge within themselves. This supports the theory of constructivism (Piaget, 1980), which encourages pupils to build their own knowledge. Applying the theory of constructivism in learning, the pupils will generate ideas to build knowledge through experience and learning environment. The constructivism theory also emphasizes on pupil-centred learning in which pupils play an active role in understanding the knowledge learned and making it more meaningful.

\section{Problem Statement}

At this present time, teaching and learning is becoming increasingly challenging due to various factors. In such situation, teaching and learning Mathematics especially have been very crucial, as the teachers are facing difficulties in making the students understand the concepts and prepare them for the exam at the end of the schooling term. It is more devastating, as the achievement of Mathematics in UPSR for 2017 and 2018 are respectively very low which raises questions and doubts about the ability of students in Mathematics. The findings indicate that from the overall enrolment of the students, $18.6 \%$ (2017) and $19.50 \%$ (2018) are still at the minimum level, which means pupils obtained grade $E$ in the exam.

From to analysis that is done, our current mathematics curriculum (KSSR) applies the basic skills of Fraction, Decimal and Percentage (FDP) and relates them to unit conversion in Whole Number, Length, Mass and Volume of Liquid. However, this approach does not help the students to master the skills despite using them numerous times in different topics. Lack of understanding basic concept and unable to master the skills were the main reasons why the pupils were not able to solve and answer their exams well which directly lead to the low achievement in Mathematics. This is proved based on the findings of the pre-test in unit conversion involving 
Fraction, Decimal and Percentage (FDP) and its relevance to unit conversion in the topics of Whole Number, Length, Mass and Volume of Liquid. This pre-test was conducted for a group of 50 pupils, which shows almost $96 \%$ of the pupils are categorized as low-level achiever and the remaining $4 \%$ fall under the medium level category.

Teachers that are still maintaining the traditional ways of teaching and learning are one of the main factors contributing to the low level of understanding and mastery of the concepts in Mathematics among the pupils. This teaching method will only encourage students to learn passively with high dependencies on teachers (Blair et al., 2016; Zainuddin \& Attaran, 2016). This is totally a teacher-centred teaching and learning that means there are no differentiation and all the pupils are taught at the same pace despite of their different abilities, skills, strengths and experiences. Such teaching strategies will also cause the learning process to be linear, bored and minimal to no usage of technology. As the outcome, pupils will lose their interest and focus towards the learning process; they get bored with the same routine and finally get lost throughout the teaching and learning process. They would not be able to grasp and master the concept and knowledge. This will eventually lead them to answer poorly in their exams hence the poor achievement in Mathematics. Therefore, the aim of this research is to explore the use of "Where's My Family Games" in order to enhance the mastery of basic skills of FDP and its relevance to the unit conversion through topics such as Whole Number, Length, Mass and Volume of Liquid.

\section{Research Methodology}

This research is a One-Group Pre-test - Post-test Experimental Design. This research involved 50 pupils from four schools. The Pre-test are done on the concepts of Fraction, Decimals and Percentages (FDP) and its relevance to unit conversion in Mathematics. This was conducted in order to identify the pupils' achievement.

The pre-test consists of 15 questions involving basic skills in Fraction, Decimal, and Percentage (FDP) and in relevance to the unit conversion in the topic of Whole Number, Length, Mass and Volume of liquid was given to the participants. After the Pre-test was conducted and analysed, implementation of teaching and learning of the FDP's basic skills and its relevance to unit conversion in the topic of Whole Number, Length, Mass and Volume of liquid and also the use of fingers in unit conversion were emphasized. "Where's My Family Games" rules are explained so that the pupils can understand the usage. According to Martlew, Stephen \& Ellis (2011), it is important to keep children engaged in the right way and to provide opportunities and space for them to master the academic skills required in formal learning. A post-test will be given to pupils involved after a few weeks.

"Where's My Family Games" fun teaching application is expected to assist pupils in mastering the FDP's basic skills and its relationship to unit conversion in the topic of Whole Number, Length, Mass and Volume of liquid. This step is important because it is the key in helping pupils' achievement in Mathematics. This game uses interesting colourful cards and pictures that are useful to teach them. "Where's My Family Games" can be diversified in various ways and 
INTERNATIONAL JOURNAL OF ACADEMIC RESEARCH IN PROGRESSIVE EDUCATION AND

DEVELOPMENT

Vol. 9, No. 2, 2020, E-ISSN: 2226-6348@ 2020 HRMARS

topics. The contents of the family and the number of cards involved in this innovation are shown in Table 1.

Table 1: Number of Family and Cards In "Where's My Family"

\begin{tabular}{|c|c|c|}
\hline Topic & Number of Family & Number of cards \\
\hline Fraction, Decimal, Percentage & 15 & 60 \\
\hline Whole Number & 15 & 60 \\
\hline Length & 45 & 180 \\
\hline Mass & 15 & 60 \\
\hline Volume of liquid & 15 & 60 \\
\hline Total & 105 & 420 \\
\hline
\end{tabular}

\section{Result and Disscussion}

Pre-test and Post-test data were analysed using descriptive statistics. After the data is collected, researchers analyse the data to measure the effectiveness of "Where's My Family Games" in helping the pupils to master FDP basic skills and its relevance to converting unit in Whole Number, Length, Mass and Volume of Liquid. Pupils' mastery level was measured before and after playing "Where's My Family Games". The level of pupils were categorized into three groups which are low, moderate and high according to the number of correct answers as shown in Table 2.

Table 2: Level of FDP Mastering Skills and in Relevance to Converting Unit in Whole Number, Length, Mass and Volume of Liquid

\begin{tabular}{cc}
$\begin{array}{c}\text { Numbers of Questions Answered } \\
\text { Correctly }\end{array}$ & Level \\
$0-6$ & Low \\
$7-11$ & Moderate \\
$12-15$ & High \\
\hline
\end{tabular}

Mean score of Pre-test and Post-test were analysed according to schools and also as overall to compare the effectiveness of Fun Teaching "Where's My Family Games" in order to enhance the FDP mastery in Whole Number, Length, Mass and Volume of Liquid. Tables and graphs are used to show comparison for both findings of Pre-test and Post-test.

Table 3 shows the analysis of Pre-test for school A, B, C, D and as in whole. School C shows the best result compared to the other schools, which only $75.00 \%$ pupils categorized in low level and $25.00 \%$ pupils, categorized in moderate level. School D shows $94.44 \%$ pupils categorized in low level and $5.56 \%$ pupils in moderate level. School A and B show $100 \%$ pupils in low level as most of them could not answer more than 6 questions correctly. In conclusion, the findings shows 48 pupils categorized in low level (96\%) and 2 pupils in moderate level (4\%). 
INTERNATIONAL JOURNAL OF ACADEMIC RESEARCH IN PROGRESSIVE EDUCATION AND DEVELOPMENT

Vol. 9, No. 2, 2020, E-ISSN: 2226-6348 @ 2020 HRMARS

Table 3 : Pre-test Result According to Category Level and Schools.

\begin{tabular}{ccccccccc}
\hline \multirow{2}{*}{ School } & \multirow{2}{*}{ Total Samples } & \multicolumn{2}{c}{ Low } & \multicolumn{3}{c}{ Moderate } & \multicolumn{2}{c}{ High } \\
& & $\mathbf{0 - 6}$ & $\mathbf{\%}$ & $\mathbf{7 - 1 1}$ & $\mathbf{\%}$ & $\mathbf{1 2 - 1 5}$ & $\mathbf{\%}$ \\
\hline A & 12 & 12 & 100.00 & 0 & 0.00 & 0 & 0.00 \\
B & 16 & 16 & 100.00 & 0 & 0.00 & 0 & 0.00 \\
C & 4 & 3 & 75.00 & 1 & 25.00 & 0 & 0.00 \\
D & 18 & 17 & 94.44 & 1 & 5.56 & 0 & 0.00 \\
\hline TOTAL & $\mathbf{5 0}$ & $\mathbf{4 8}$ & $\mathbf{9 6 . 0 0}$ & $\mathbf{2}$ & $\mathbf{4 . 0 0}$ & $\mathbf{0}$ & $\mathbf{0 . 0 0}$ \\
\hline
\end{tabular}

Next is the post-test analysis for School A, B, C, D and as in whole shown in Table 4. The analysis shows that all the pupils in School C scored $100 \%$ and categorized in high-level category. Meanwhile, $44.44 \%$ pupils in School $\mathrm{D}$ are in high-level category, $50.00 \%$ in moderate category and $5.56 \%$ in low category. School A shows $25.00 \%$ pupils categorized in high-level, $50.00 \%$ in moderate category and $25.00 \%$ in low category. Where else, in school B none is categorized in high-level category, $62.50 \%$ in moderate level category and $37.50 \%$ in low-level category. As conclusion, Post-test findings shows there is an increment, which is 15 pupils categorized in high level (30\%), 25 pupils in moderate level (50.00\%) and only 10 pupils in low level $(20 \%)$.

Table 4: Post-test Result According Category Level and Schools.

\begin{tabular}{cccccccc}
\hline \multirow{2}{*}{ School } & \multirow{2}{*}{ Total Sample } & \multicolumn{2}{c}{ Low } & \multicolumn{2}{c}{ Moderate } & \multicolumn{2}{c}{ High } \\
& & $\mathbf{0 - 6}$ & $\mathbf{\%}$ & $\mathbf{7 - 1 1}$ & $\mathbf{\%}$ & $\mathbf{1 2 - 1 5}$ & $\mathbf{\%}$ \\
\hline A & 12 & 3 & 25.00 & 6 & 50.00 & 3 & 25.00 \\
B & 16 & 6 & 37.50 & 10 & 62.50 & 0 & 0.00 \\
C & 4 & 0 & 0.00 & 0 & 0.00 & 4 & 100.00 \\
D & 18 & 1 & 5.56 & 9 & 50.00 & 8 & 44.44 \\
\hline TOTAL & $\mathbf{5 0}$ & $\mathbf{1 0}$ & $\mathbf{2 0 . 0 0}$ & $\mathbf{2 5}$ & $\mathbf{5 0 . 0 0}$ & $\mathbf{1 5}$ & $\mathbf{3 0 . 0 0}$ \\
\hline
\end{tabular}

Table 5 and Figure 1 shows the comparison of Pre-test and Post-test for all the four schools and as in whole. The result shows that all the schools increment in the mastery of basic FDP mastery in Whole Number, Length, Mass and Volume of Liquid after using the innovation "Where's My Family Games".

Table 5: Comparison of Pre-test and Post-test

\begin{tabular}{ccccccc}
\hline \multirow{2}{*}{ School } & \multicolumn{2}{c}{ Low } & \multicolumn{2}{c}{ Moderate } & \multicolumn{2}{c}{ High } \\
& Pre & Post & Pre & Post & Pre & Post \\
\hline A & 100.00 & 25.00 & 0.00 & 50.00 & 0.00 & 25.00 \\
B & 100.00 & 37.50 & 0.00 & 62.50 & 0.00 & 0.00 \\
C & 75.00 & 0.00 & 25.00 & 0.00 & 0.00 & 100.00 \\
D & 94.44 & 5.56 & 5.56 & 50.00 & 0.00 & 44.44 \\
\hline Overall & $\mathbf{9 6 . 0 0}$ & $\mathbf{2 0 . 0 0}$ & $\mathbf{4 . 0 0}$ & $\mathbf{5 0 . 0 0}$ & $\mathbf{0 . 0 0}$ & $\mathbf{3 0 . 0 0}$ \\
\hline
\end{tabular}




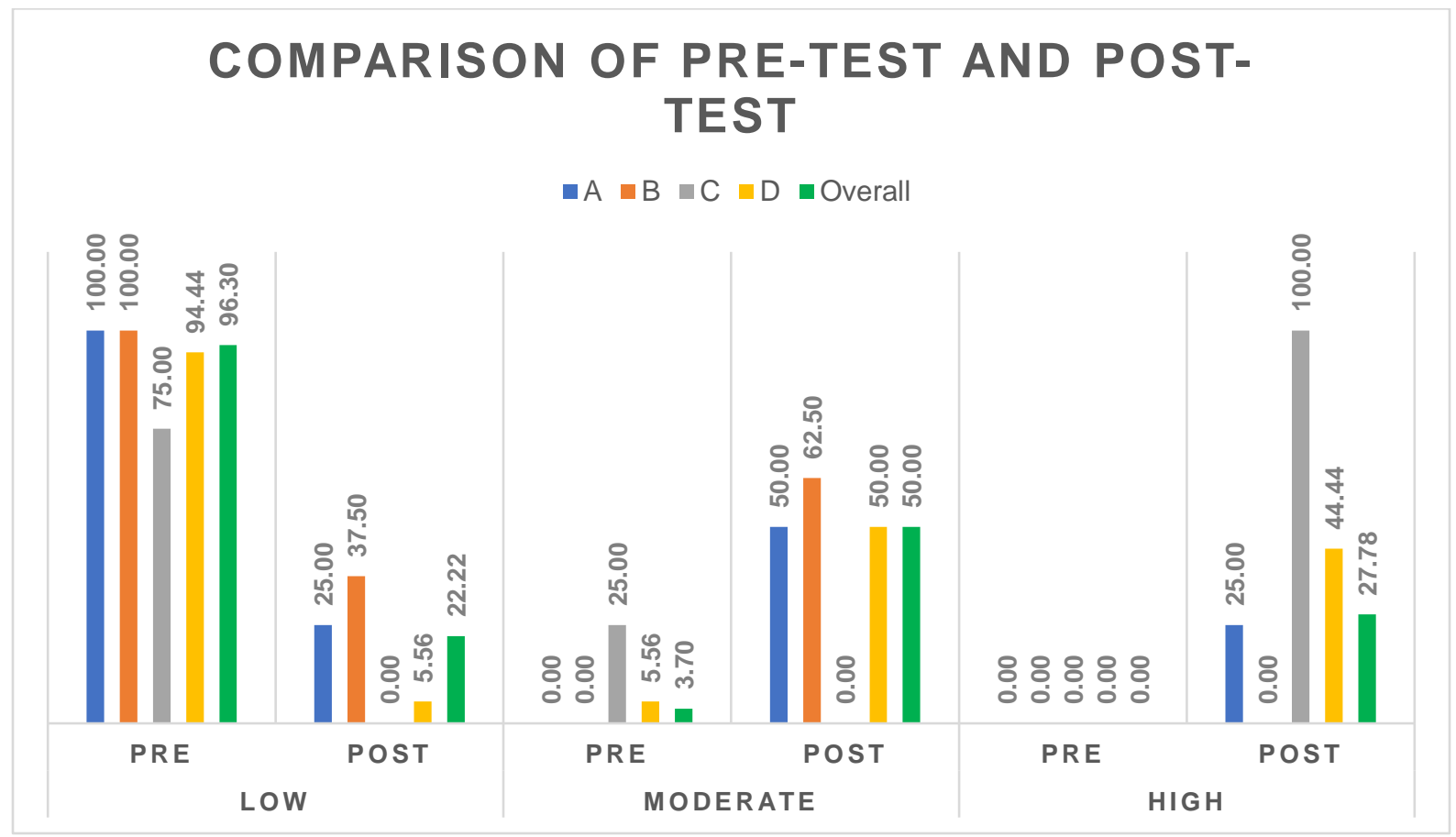

Figure 1: Comparison of Pre-test and Post-test

Mean score for Pre-test and Post-test for all the schools showed in Table 6. Mean score for School $C$ shows the highest increment, which is $71.67 \%$. School D shows the second highest increment from $8.89 \%$ to $70.74 \%$ while School A shows increment of $61.11 \%$. School B shows the lowest increment of mean score that is from $4.17 \%$ to $48.33 \%$. Overall, mean score for pre-test increased from $6.93 \%$ to $63.73 \%$ post-test with the increment of $56.80 \%$.

Table 6: Mean Score of Pre-test and Post-Test According School and as in Whole

\begin{tabular}{ccccc}
\hline School & Total pupil & Pre-test & Post-test & Difference \\
& & & & \\
\hline A & 12 & 2.22 & 63.33 & 61.11 \\
B & 16 & 4.17 & 48.33 & 44.17 \\
C & 4 & 23.33 & 95.00 & 71.67 \\
D & 18 & 8.89 & 70.74 & 61.85 \\
\hline Overall & $\mathbf{5 0}$ & $\mathbf{6 . 9 3}$ & $\mathbf{6 3 . 7 3}$ & $\mathbf{5 6 . 8 0}$ \\
\hline
\end{tabular}




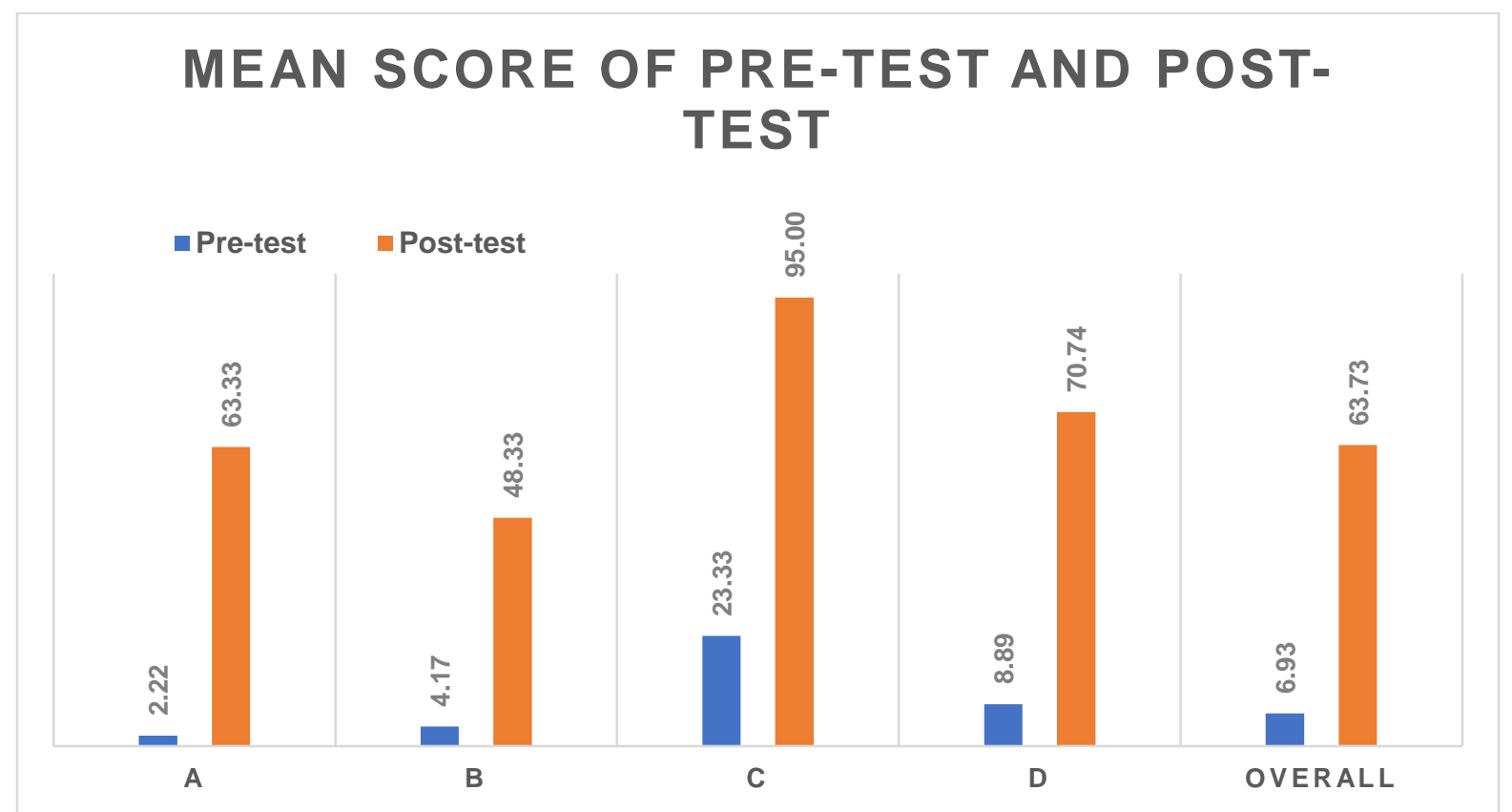

Figure 2: Comparison of Mean Score of Pre-test and Post-test According to Schools and as in Whole

Finding shows "Where's My Family Games" with the use of fingers and Fun Teaching Flash Card has successfully helped pupils in mastering and elevating their achievement in converting units in Whole Number, Length, Mass and Volume of Liquid, which involve Fraction, Decimal and Percentage (FDP). The use of "Where's My Family Games" also encourage pupils to be actively involved and to shape deep understanding on the concept of converting units.

This is because the use of "where's my family games" is an approach of fun teaching where it can attract pupils' interest and attention towards mathematics. This statement is supported by Presky (2007); Darwish, Abdo, \& Alshuwaiee, (2018), states that games is useful in learning process due to two factors which are interactive and attract pupil's attention. According to Ismail, Idros and Samsudin (2006), fun learning encourages active knowledge construction during the process of learning in conjunction with constructivism approach which emphasizes individual role, the importance of building meaningfulness and the active role as a learner. This will help pupils to increase the knowledge and performance in learning mathematics.

The application of "Where's My Family Games" is seen supporting the Constructivism Learning Theory of Piaget (1980). This is because "Where's My Family Games" encourages selflearning that is pupil centred. This can help pupils to build up their mathematical knowledge through assimilation or accommodation and enables knowledge to be always organized in the form of cognitive. It will help to increase pupil's understanding in converting unit, which involves Fraction, Decimal and Percentage (FDP). 


\section{Conclusion}

The application of "Where's My Family Games" among the pupils motivate them to actively participate and understand the concept of unit conversions. It is clear when during the usage of "Where's My Family Games" pupils can be seen helping and guiding their peers. Understanding and explaining the concepts to peers certainly helps to create a positive ambience for students to refine their thinking and deepening their knowledge in particular topic. Therefore, we can conclude that, if a correct, suitable approach or strategy is used for the teaching and learning, it will help in boosting the confidence level among the pupils and therefore the understanding of the concepts will be delivered successfully. The impact of "Where's My Family Games" also encourages the teachers to diversify their approach inside the classroom, which means the pupils construct own understandings and knowledge through experiences and reflecting their experiences, this supports constructivism-learning theory on student centered learning.

\section{Corresponding Author}

Kho Ling Hong and Izzat Syahir Mohd Ramli

Pejabat Pendidikan Daerah Subis, 98150 Bekenu, Sarawak, Malaysia

Email: linghongkho@gmail.com; ejat.mu89@gmail.com

\section{References}

Ali, A., Aziz, Z., \& Majzub, R. (2011). Teaching and Learning Reading Through Play. World Applied Sciences: Journal 14, 15-20.

Blair, E., Maharaj, C., \& Primus, S. (2016). Performance and perception in the flipped classroom. Education and Information Technologies, 21(6), 1465-1482.

Darwish, S., Abdo, H., \& AlShuwaiee, W. M. (2018). Opportunities, challenges and risks of transition into renewable energy: the case of the Arab Gulf Cooperation Council. International Energy Journal, 18(4).

Emery J., H.-M., \& Johannes, S. (2007). Constructivism and Education: Misunderstandings and Pedagogical Implications. The Teacher Educator 43(1): 72-86.

Martlew, J., Stephen, C., \& Ellis, J. (2011). Play in the primary school classroom? The experience of teachers supporting children's learning through a new pedagogy. Early Years, 31(1), 7183.

Rashid, A., Boon, N., Pong, Y., Fakhriah, S. A. (2015). Murid dan Alam Belajar. Edisi Kedua. Kuala Lumpur: Oxford Fajar Sdn. Bhd.

Piaget, J. (1980). Experiments in contradiction. Chicago: The University of Chicago Press.

Prensky, M. (2007). How to teach with technology: keeping both teachers and pupils comfortable in an era of exponential change. Learning, 2, 40-46.

Zainuddin, Z. \& Attaran, M. (2016). Malaysian pupils' perceptions of flipped classroom: a case research. Innovations in Education and Teaching International, 53(6), 660-670.

Ismail, Z., Idros, S. N., \& Samsudin, M. A. (2006). Siri Pembangunan Profesion Perguruan: Kaedah Mengajar Sains. Pahang Darul Makmur: PTS Professional Publishing Sdn. Bhd 